\title{
Sources of high protein and gluten content in grain in some wheat species
}

Askhadullin D-r F. ${ }^{*}$, Askhadullin D-1 F. ${ }^{1}$, Vasilova N.Z. ${ }^{1}$, Khusainova I.I. ${ }^{1}$, Tazutdinova M.R. ${ }^{1}$, Bagavieva E.Z. ${ }^{1}$, Zuev E.V. ${ }^{2}$

${ }^{1}$ Tatar Scientific Research Institute of Agriculture, KSC RAS, Kazan, Russia

${ }^{2}$ N.I. Vavilov All-Russian Institute of Plant Genetic Resources (VIR), St. Petersburg, Russia

*e-mail:trulik@ya.ru

Despite the creation of a number of varieties of soft wheat combining high grain productivity and high grain quality, there are limits to increasing protein and gluten. The initial material plays a key role in the efficiency of selection for grain quality. Screening of the VIR wheat collection on the NIR analyzer, grown in the forest-steppe zone of the Republic of Tatarstan, revealed samples with the highest protein and gluten content. They can serve as a starting material for the selection of high-quality varieties of soft wheat. During three years (2016-2018) wheat samples including the following species were analyzed: T. aestivum L., T. durum Desf., T. dicoccum (Schrank) Schuebl., T. polonicum L. In high-protein samples T. aestivum L. protein content in grain ranged from 15 to $18.7 \%$, gluten in grain from 32.8 to $38.1 \%$. The maximum protein and gluten content was in varieties Long Fu 12 (K-65473, China), Long Fu 040671 (K-66200, China), Krasnoufimskaya 110 (K-65478, Russia, Sverdlovsk region), Ekaterina (K65477, Russia, Sverdlovsk region), AC Taho (K-64977, Canada), Lillian (K-66203, Canada), Lovitt(K-66204, Canada), Molera (K-66033, Switzerland), Pamyati Maistrenko (K-65448, Russia, Omsk region), Polyushko (K-64856, Russia, Novosibirsk region), Manu (K-66029, Finland), Mayon 1 (K-65851, Syria). T. durum Desf. is widely used in hybridization with soft wheat and can be a source of high protein content. The maximum protein content was $16.4 \%$ in the sample of Bezenchukskaya 182 (K-59890, Samara region), in other tested samples it did not exceed $15 \%$. Species T. dicoccum (Schrank) Schuebl, refers to high-protein, protein content in some samples reached $18.2 \%$, while the starch content is slightly lower than that of high-quality spring wheat. Protein content stand out K-7530 (Russia, Ulyanovsk region), K-10456 (Russia, Tatarstan), K-21961 (Germany). High protein content in T. polonicum L. - reached $17.8 \%$. The maximum protein and gluten content was in K-9277 (Israel) and Koko (K-62974, Syria). 